\title{
Pengaruh pemberian aroma terapi bunga mawar terhadap tingkat nyeri dismenorea pada siswi SMA
}

\author{
Ratna Sari*, Dainty Maternity, Rosmiyati \\ Program Studi DIV Kebidanan Universitas Malahayati. *Email: ratna6937@gmail.com
}

\author{
Abstract \\ The effects of aromatherapy with rose oils in premenstrual pain and primary dysmenorrhea \\ among high school girls
}

Background : Dysmenorrhea is menstrual cramps during menstruation that usually occurs in the lower or back of the abdomen. In Indonesia the incidence of dysminorrhoea was $64.25 \%$, which experienced primary dysmenorrhoea at $54.89 \%$ while the rest were secondary type sufferers. One non-pharmacological treatment that can be used to treat pain in disminore is to use rose aromatherapy.

Purpose : To known The effects of aromatherapy with rose oils in premenstrual pain and primary dysmenorrhea among high school girls

Method: A quantitative a quasy experimental approach with a two group pretest-posttest design. The population was all high school girls. The sampling technique used purposive sampling as many as 30 high school girls who has experienced of premenstrual pain and primary dysmenorrhea . Bivariate analysis using independent t-test.

Results: Obtained an average of pain during menstruation in the group before being given an intervention of 7,420 , after intervention 3,767 , pretest pain in the control group of 7,040 , after in the control group of 7,053 . The independent sample T-test results obtained $p$ value $0,000<0.05$.

Conclusion: There was a effects of aromatherapy with rose oils in premenstrual pain and primary dysmenorrhea among high school girls

Keywords: Aromatherapy; Rose oils; Premenstrual pain; Primary dysmenorrheal; High school girls

Pendahuluan: Dismenore adalah kram perut saat menstruasi yang biasa terjadi pada perut bagian bawah atau belakang. Di Indonesia angka kejadian disminorea sebesar $64,25 \%$, yang mengalami dismenorea primer sebesar $54,89 \%$ sedangkan sisanya adalah penderita tipe sekunder. Salah satu pengobatan non farmakologi yang dapat digunakan untuk mengatasi nyeri pada disminore adalah dengan menggunakan aromatherapy mawar.

Tujuan : Untuk mengetahui pengaruh pemberian minyak essensial mawar pada siswi yang mengalami dismenorea di SMA Persada Kota Bandar Lampung Tahun 2019.

Metode : Penelitian kuantitatif menggunakan pendekatan quasy eksperimen dengan rancangan two group pretest-posttest design. Populasi penelitian adalah seluruh remaja putri di SMA Persada Bandar Lampung dengan sampel menggunakan purposive sampling sebanyak 30 remaja putri yang mengalami dismenore setiap menstrasi. Analisa bivariat dengan menggunakan uji t-test independent.

Hasil : Diperoleh rata-rata nyeri saat menstruasi pada kelompok sebelum diberi intervensi sebesar 7,420, setelah intervensi 3,767 , nyeri pretes pada kelompok kontrol sebesar 7,040, setelah pada kelompok kontrol 7,053. Hasil uji T-test sample independent diperoleh nilai $p$ value $0,000<0,05$.

Simpulan: Ada pengaruh nyeri dismenorea dengan pemberian minyak essensial mawar pada siswi di SMA Persada Kota Bandar Lampung Tahun 2019.

\section{Kata kunci : Aroma terapi; Bunga mawar; Tingkat nyeri; Dismenorea}

\section{PENDAHULUAN}

Masa remaja merupakan masa transisi atau peralihan dari masa anak menujuu dewasa yang ditandai denngan perubahan baik fisik maupun psikis. Perubahan fisik yang nampak jelas tubuh berkembang pesat mencapai bentuk tubuh orang dewasa yang disertai dengan perkembangan kapasitas reproduksi (Proverawati \& Misaroh, 2010; Felicia, Hutagaol, \& Kundre, 2015). Angka kejadian dismenorea diindonesia sebesar $64,25 \%$, yang mengalami dismenorea primer sebesar $54,89 \%$ sedangkan sisanya adalah 
Pengaruh pemberian aroma terapi bunga mawar terhadap tingkat nyeri dismenorea pada siswi SMA

penderita tipe sekunder. Dismenorea menyebabkan $14 \%$ dari pasien remaja sering tidak hadir disekolah dan tidak menjalani kegiatan sehari-hari (Proverawati \& Misaroh, 2009). Segolongan perempuan yang mengalami diemenorea primer mengatasi serta menyembuuhkan nyeri haid tersebut dengan mengkonsumsi obat-obatan. Namun sifat obatobatan tersebut hanya menghilangkan rasa nyeri, maka penderita akan mengalami ketergantungan obat dalam jangka panjang. Apabila dikonsuumsi terus menerus akan menimbulkan dampak negatif bagi kesehatan (Anurogo \& Wulandari, 2011). Penatalaksanaan nyeri menstruasi juga dapat dimanajemen secara non farmakologi seperti teknik distraksi, teknik reaksasi, teknik stimulasi kulit dan pemberian aromatherapy. Teknik pemberian aromatherapy bisa menggunakan berbagai macam aromatherapy misalnya mawar (Potter, Perry, Hall, \& Stockert, 2015).

Aromatherapy bunga mawar merupakan suatu cara perawatan tubuuh dan atau penyembuhan penyakit dengan menggnakan minyak essensial ( essensial oil ). Minyak essensial ini dapat mempengaruhi aktivitas otak melali sistem saraf yang berhubungan denagn indra penciuman sehingga merangsang peningkatan neurotransmitter yang berkaitan dengan pemulihan kondisi psikis seperti emosi, perasaan, pikiran dan keinginan. Aromatherapi mawar memiliki manfaat ntuk mengobati sakit selama menstruasi. Selain itu aromatherapi bunga mawar jga membantu melancarkan pengeluaran darah kotor selama menstruasi (Ardela, Yuliwar, \& Dewi 2017; Nursangadah, 2019; Sardjono \& Fevriasanty 2016).

Penggunasan aromatherai mawar dapat menambahkan perasaan tenang pada jasmani, pikiran, dan rohani. Aromatherapi mawar juga memiliki efek analgetik lokal dan antispasmodik. Bau yang menyenangkan akan merangsang hopofisis mengeluarkan endorphin yang berfungsi sebagai penghilang rasa sakit alami dan menghasilkan perasaan rileks, tenang dan senang. Rasa tenang akan merangsang daerah di otak yang disebut raphe untuk mensekresi serotinin yang memberikan efek sedatif, dan relaksasi (Fatima, Ratna \& Mardalena, 2018; Koesoemardiyah, 2010; Hikmah, Amelia \& Ariani 2018; Lee, Lee, Khalil, Lim \& Lim, 2018).

\section{METODE PENELITIAN}

Penelitian kuantitatif, dan rancangan menggunakan pendekatan quasi eksperimen dengan rancangan penelitian two group pretestposttest design. Populasinya seluruh remaja putri di SMA Persada Kota Bandar Lampung, dengan sampel berjumlah 30 partisipan dimana 15 merupakan kelompok kontrol dan 15 kelompok intervensi. Sebelumnya kelompok kontrol dan intervensi diberilakukan penilaian Nyeri, selanjutnya tahapan pada kelompok intervensi menghirup esssensial oil atau sari minyak murni yang mengandung mawar sebanyak tiga tetes yang diteteskan di tissue dan dihirup dengan jarak 7-10 CM selama 5 (lima) menit kemudian dilakukan evaluasi setelah 6 (enam) jam kemudian nilai diukur nyeri disminorea dengan menggunakan skala ukur VAS (Visual Analoge Scale) (0-15) (Ardela, Yuliwar, \& Dewi, 2017). Surat layak etik didapatkan dari komisi etik penelitian Universitas Malahayati dengan no surat No. 428/EC/KEP-UNMAL/VII/2019 
HASIL

Tabel 1. Karakteristik Responden (Kelompok Intervensi) ( $\mathrm{N}=15$ )

\begin{tabular}{lcc}
\hline Karakteristik & Frekuensi (f) & Persentase (\%) \\
\hline Usia: & & \\
15 tahun & 4 & 26.7 \\
16 tahun & 8 & 53.3 \\
17 tahun & 3 & 20.0 \\
& & \\
IMT: & & \\
Normal (18.5-25) & 15 & 100.0 \\
& & \\
Usia Menarch: & & 26.6 \\
10 tahun & 4 & 40.0 \\
11 tahun & 6 & 33.4 \\
12 tahun & 5 & \\
& & \\
Siklus Menstruasi: & & 20.0 \\
21 hari & 3 & 80.0 \\
28 hari & 12 & \\
& & 13.3 \\
Lama menstruasi: & & $\mathbf{2 6 . 7}$ \\
4 hari & 2 & 33.3 \\
5 hari & 4 & $\mathbf{2 6 . 7}$ \\
6 hari & 5 & \\
7 hari & 4 & \\
\hline
\end{tabular}

Tabel 2.Pengaruh Pemberian Aroma Terapi Bunga Mawar Terhadap Tingkat Nyeri Dismenorea

\begin{tabular}{lccccccc}
\hline Variabel & $\mathbf{N}$ & Mean & Median & SD & Min & Max & $\mathbf{P}$ \\
\hline $\begin{array}{l}\text { Nyeri Haid Sebelum } \\
\text { (kelompok Intervensi) }\end{array}$ & 15 & 7,420 & 7,700 & 0,7523 & 6,2 & 8,9 & $\mathbf{0 , 0 0 0}$ \\
$\begin{array}{l}\text { Nyeri Haid Setelah } \\
\text { (kelompok Intervensi) }\end{array}$ & 15 & 3,767 & 4,000 & 0,7394 & 2,3 & 5,1 & \\
$\begin{array}{l}\text { Nyeri Haid sebelum pada } \\
\text { (kelompok kontrol) }\end{array}$ & 15 & 7,040 & 7,100 & 0,5329 & 6,2 & 7,9 & $\mathbf{0 , 1 5 4}$ \\
$\begin{array}{l}\text { Nyeri Haid sesudah pada } \\
\text { (kelompok kontrol) }\end{array}$ & 15 & 7,053 & 6,900 & 0,5153 & 6,2 & 7,8 & \\
\hline
\end{tabular}

Pada tabel 2. pada kelompok intervensi terlihat adanya perbedaan nilai mean sebelum intervensi 7,420 sedangkan setelah intervensi nilai means sebesar 3,767 dengan nilai $V$ palue 0,000 sedangkan pada kelompok kontrol terlihat ada penurunan nyeri haid namun tidak terlalu signifikan dengan nilai means sebelum intervensi 7,040 dan setelah pada kelompok kontrol 7,053 dengan hasil uji beda 0,154 yang artinya tidak ada perbedaan secara signifikan.

\section{PEMBAHASAN}

Disminorea merupakan nyeri yang terjadi pada saat menstruasi yang disebabkan oleh peningkatan hormon prostaglandin. Dismenore dirasakan pada perut bagian bawah yang bisa menjalar ke punggung bagian bawah dan tungkai. 
Pengaruh pemberian aroma terapi bunga mawar terhadap tingkat nyeri dismenorea pada siswi SMA

Dismenore terdiri dari primer dan sekunder, dismenore primer disebabkan tanpa ada masalah ginekologi yang terjadi setelah menarche hingga usia 25 tahun dan dismenore sekuder disebabkan oleh kelainan ginekologi yang dialami diatas usia 25 tahun (Sukarni \& Wahyu, 2013; Larasati \& Alatas, 2016; Puji, 2009).

Dari hasil penelitian didapatkan adanya pengaruh pemberian minyak essensial bungan mawar terhada nyeri disminorea dengan nilai $p$ value 0,000 hal ini di sebabkan karena aroma terapi mawar dapat menumbuhkan perasaan tenang pada jasmani, pikiran dan rohani. Aroma terapi mawar juga memiliki efek analgenitik lokal dan anti spasmodik. Selain itu, bau yang menyenangkan akan merangsang hipofisis mengeluarkan endorfin yang berfungsi sebagai penghilang rasa sakit alami dan penghilang rasa sakit (Koesomardiah, 2009; Pramita, Rahmawati \& Antono, 2017; Handayani, Mintarsih, \& Rohmatin, 2018; Putri, Purwaningsih \& Hartutik, 2019).

Berdasarkan hasi penelitian dimana penurunan pengukuran skala nyeri sebelum dan sesudah diberikan aroma terapi mawar berbeda-beda, hal tersebut teradi karena dipegaruhi oleh faktor lain, seperti usia, imt, usia menarce, siklus menstrasi dan lama menstruaisi sehingga respon terhadap remaja putri juga tidak sama antara satu dengan remaja lainnya. Hasil penelitian ini sejalan dengan penelitian sebelumnya. Dengan hasil penelitian didapatkan tingkat nyeri yang dirasakan oleh remaja putri tersebut berbeda-beda hal tersebut disebabkan faktor usia, IMT usia menarhce, siklus menstruasi dan lama menstruasi (Hikmah, Amelia \& Ariani , 2018; Handayani, Mintarsih, \& Rohmatin, 2018).

\section{SIMPULAN}

Setelah dilakukan penelitian dengan hasil yang didapatkan; adanya Pengaruh pemberian aroma terapi bunga mawar terhadap tingkat nyeri dismenorea dengan nilai $p$-value $0,000 \leq 0,05$

\section{SARAN}

Diharapkan intervensi pemberian aroma terapi bunga mawar dapat diterapkan sebagai terapi alternatif untuk menurunkan tingkat nyeri dismenorea pada remaja putri.

\section{DAFTAR PUSTAKA}

Anurogo, D., \& Wulandari, A. (2011). Cara jitu mengatasi nyeri haid. Yogyakarta: Andi.

Ardela, M., Yuliwar, R., \& Dewi, N. (2017). Efektivitas Relaksasi Nafas Dalam dan Relaksasi Aromaterapi Bunga Mawar Terhadap Perubahan Nyeri Pada Remaja yang Mengalami Dysmenorrhea Primer Di Kecamatan Lowokwaru Malang. Nursing News: Jurnal IImiah Keperawatan, 2(1).

Fatimah, O. R., Ratna, W., \& Mardalena, I. (2018). Pengaruh pemberian aromaterapi lemon essential oil terhadap mual muntah pasca operasi sectio caesarea dengan spinal anestesi di RSKIA Sadewa Yogyakarta (Doctoral dissertation, Poltekkes Kemenkes Yogyakarta).

Felicia, F., Hutagaol, E., \& Kundre, R. (2015). Hubungan status gizi dengan siklus menstruasi pada remaja putri di PSIK FK UNSRAT Manado. Jurnal Keperawatan, 3(1).

Handayani, R. S., Mintarsih, P.W, \& Rohmatin, E. (2018). Perbandingan Pengaruh Aromaterapi Mawar Dan Massage Effleurage Terhadap Nyeri Persalinan Kala I Fase Aktif. Jurnal Bidan, 4(2), 267039.

Hikmah, N., Amelia, C. R., \& Ariani, D. (2018). Pengaruh Pemberian Masase Effleurage Menggunakan Minyak Aromaterapi Mawar terhadap Penurunan Intensitas Nyeri Dismenore pada Remaja Putri di SMK Negeri 2 Malang Jurusan Keperawatan. Journal of Issues in Midwifery, 2(2), 34-45.

Koensoemardiyah, S. (2010). A to Z Minyak Atsiri untuk Industri Makanan, Kosmetik dan Aromaterapi. Yogyakarta: CV Andi Offset.

Larasati, T. A., \& Alatas, F. (2016). Dismenore primer dan faktor risiko Dismenore primer pada Remaja. Jurnal Majority, 5(3), 79-84.

Lee, M. S., Lee, H. W., Khalil, M., Lim, H. S., \& Lim, H. J. (2018). Aromatherapy for managing pain in primary dysmenorrhea: A systematic 
Pengaruh pemberian aroma terapi bunga mawar terhadap tingkat nyeri dismenorea pada siswi SMA

Nursangadah, S. (2019). Aplikasi massage effleurage menggunakan minyak aromaterapi mawar untuk mengatasi nyeri akut pada remaja dengan dismenore (Doctoral dissertation, Skripsi, Universitas Muhammadiyah Magelang).

Potter, P. A., Perry, A. G. E., Hall, A. E., \& Stockert, P. A. (2015). Fundamentals of nursing. Elsevier mosby.

Pramita, D. R. P., Rahmawati, R. S. N., \& Antono, S. D. (2017). Perbedaan intensitas nyeri tehnik pemberian kompres air hangat dan aroma terapi mawar pada ibu bersalin kala I fase aktif. Jurnal IImu Kesehatan, 6(1), 90-100.

Proverawati, A., \& Misaroh, S. (2010). Menarche menstruasi pertama penuh makna. Yogyakarta: Nuha Medika, 144.
Puji, A. I. (2009). Efektivitas senam dismenore dalam mengurangi dismenore pada remaja putri di SMU N 5 Semarang. Retrieved Octo, 24, 2010.

Putri, D. R. S., Purwaningsih, W., \& Hartutik, S. (2019). Penerapan massage effleurage menggunakan minyak aromaterapi mawar untuk menurunkan skala dismenore pada remaja putri di desa Mlandang, Manjungan, Ngawen, Klaten

Sardjono, T. W., \& Fevriasanty, F. I. (2016). Perbandingan Efektifitas Antara Aromaterapi Bunga Mawar dengan Masase dalam Menurunkan Intensitas Nyeri pada Dismenore Primer dengan Perlakuan Standar Kompres Hangat. Majalah Kesehatan FKUB, 1(3), 137148.

Sukarni, I., \& Wahyu, P. (2013). Buku ajar keperawatan maternitas. Yogyakarta: Nuha Medika. 